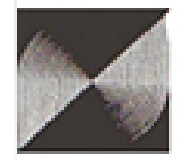

\section{Assicuttusa, \\ Sociedady Desassollo}

Agricultura, Sociedad y Desarrollo

ISSN: $1870-5472$

asyd@colpos.mx

Colegio de Postgraduados

México

Vázquez-García, Verónica; Pérez-Olvera, Ma. Antonia; Muñoz-Rodríguez, Carolina DESARROLLO, GÉNERO Y EL DERECHO HUMANO AL AGUA. UN ESTUDIO COMPARATIVO EN HIDALGO, MÉXICO

Agricultura, Sociedad y Desarrollo, vol. 11, núm. 3, julio-septiembre, 2014, pp. 295-314

Colegio de Postgraduados

Texcoco, Estado de México, México

Disponible en: http://www.redalyc.org/articulo.oa?id=360533100003

Cómo citar el artículo

Número completo

- Más información del artículo

- Página de la revista en redalyc.org

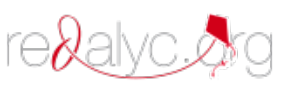

Sistema de Información Científica

Red de Revistas Científicas de América Latina, el Caribe, España y Portugal Proyecto académico sin fines de lucro, desarrollado bajo la iniciativa de acceso abierto 


\title{
DESARROLLO, GÉNERO Y EL DERECHO HUMANO AL AGUA. UN ESTUDIO COMPARATIVO EN HIDALGO, MÉXICO
}

\author{
DEVELOPMENT, GENDER AND THE HUMAN RIGHT TO WATER : A COMPARATIVE STUDY \\ IN HIDALGO, MÉXICO
}

Verónica Vázquez-García ${ }^{1}$, Ma. Antonia Pérez-Olvera ${ }^{1}$, Carolina Muñoz-Rodríguez ${ }^{2}$

\begin{abstract}
${ }^{1}$ Desarrollo Rural, Colegio de Postgraduados, Carretera Federal México-Texcoco Km. 36.5, Montecillo. Estado de México. 56230. (verovazgar@yahoo.com.mx, molvera@colpos.mx) ${ }^{2}$ División de Ciencias Sociales y Humanidades, Universidad Autónoma Metropolitana, Unidad Xochimilco, Calzada del Hueso 1100, Col. Villa Quietud, México D. F. 04960. (ingcmr77@ hotmail.com)
\end{abstract}

\section{RESUMEN}

La ampliación de la cartera de derechos humanos, más allá de la democracia formal (el derecho a votar), ha mantenido vivas las posibilidades de construir una sociedad incluyente. Uno de los derechos recientemente adquiridos es el derecho al agua. El presente artículo analiza el ejercicio de éste por parte de las mujeres en relación con cuatro indicadores: servicios de la vivienda, disponibilidad, calidad y eficiencia en la gestión del agua. La investigación fue realizada en dos ejidos del estado de Hidalgo: Colonia Veracruz (CV) y San Pedrito (SP). Para obtener información se recurrió a varios métodos: un taller, entrevistas y recorridos exploratorios, dos cuestionarios y análisis de calidad biológica del agua. Los resultados muestran que CV es un ejido con mejores indicadores de crecimiento económico (aportes al Producto Interno Bruto) y servicios de agua en la vivienda, pero tiene problemas de escasez y calidad del agua. Por el contrario, SP se encuentra en una región identificada como pobre que, sin embargo, cuenta con un sistema eficiente para la gestión del agua, asunto que se traduce en mayor disponibilidad y calidad. Se concluye que las mujeres de SP están en mejores condiciones de ejercer su derecho al agua.

Palabras clave: agua, calidad, disponibilidad, gestión, servicios.

\section{INTRODUCCIÓN}

$\mathrm{E}$ n México existe una cobertura de agua potable y drenaje de $89.8 \%$ y $89.6 \%$, respectivamente. Sin embargo, hay un abasto diferenciado entre las distintas regiones que conforman

* Autor responsable * Author for correspondence. Recibido: marzo, 2014. Aprobado: julio, 2014.

Publicado como ARTíCULO en ASyD 11: 295-314. 2014.

\begin{abstract}
The expansion of the portfolio of human rights beyond formal democracy (the right to vote), has kept alive the possibilities of building an inclusive society. One of the rights recently acquired is the right to water. This article analyzes the exercise of this right by women in regard to four indicators: household services, availability, quality and efficiency in water management. The research was performed in two ejidos of the state of Hidalgo: Colonia Veracruz $(\mathrm{CV})$ and San Pedrito (SP). In order to obtain information, several methods were used: a workshop, interviews and exploratory visits, two questionnaires and analysis of the biological quality of water. The results show that $\mathrm{CV}$ is an ejido with better indicators of economic growth (contribution to the Gross Domestic Product) and water services in the household, although there are problems of scarcity and quality of water. On the contrary, SP is found in a region identified as poor which, nevertheless, has an efficient system for water management, something that translates into greater availability and quality. It is concluded that women in SP are in better conditions to exercise their right to water.
\end{abstract}

Key words: water, quality, availability, management, services.

\section{INTRODUCTION}

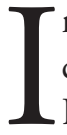
n México, there is drinking water and drainage coverage of $89.8 \%$ and $89.6 \%$, respectively. However, there is differentiated supply among the different regions that make up the country (Domínguez et al., 2013). The north, center and northwest zones concentrate $77 \%$ of the population, generate $87 \%$ of the Gross Domestic Product (GDP) and have $31 \%$ of renewable water, while $23 \%$ of the 
al país (Domínguez et al., 2013). Las zonas norte, centro y noroeste concentran $77 \%$ de la población, generan $87 \%$ del Producto Interno Bruto (PIB) y tienen $31 \%$ del agua renovable, mientras que en el sur y el sureste habita $23 \%$ de la población, se genera $13 \%$ del PIB y se encuentra $69 \%$ del agua renovable. Es decir, en el sur y el sureste hay más agua, al tiempo que se registran importantes rezagos en la cobertura de servicios de agua potable y alcantarillado (Nazar et al., 2010). A esta realidad se suman las diferencias al interior de circunscripciones territoriales específicas. Las zonas rurales tienen una cobertura de $75.7 \%$ de agua potable, mientras que en las ciudades el porcentaje es 20 puntos más alto (95.6\%) (SEMARNAT, 2012).

En su artículo 14 bis 5, la Ley de Aguas Nacionales establece que el uso público de agua para centros de población tiene prioridad sobre otros. Sin embargo, las concesiones de CONAGUA no siempre atienden este señalamiento y los capitales trasnacionales (mineras, agroindustrias) tienden a predominar sobre otros intereses (CEMDA et al., 2011). La privatización de los recursos naturales se ha incrementado en los últimos años como resultado de la liberación comercial y la globalización (García, 2008; Bello, 2008). Ante esta problemática, organismos internacionales y organizaciones sociales han promovido el reconocimiento del derecho humano al agua, el cual es definido por el Pacto Internacional de Derechos Económicos, Sociales y Culturales (PIDESC) como aquel que permite "disponer de agua suficiente, salubre, aceptable, accesible y asequible para el uso personal y doméstico" (PIDESC citado en Domínguez et al., 2013:20). Tal derecho fue ratificado en México en 2012 con la modificación al Artículo 4 de la constitución para afirmar que "toda persona tiene derecho al acceso, disposición y saneamiento de agua para consumo personal y doméstico en forma suficiente, salubre, aceptable y asequible" (en Domínguez et al., 2013:36).

El cumplimiento del derecho humano al agua es requisito indispensable para alcanzar muchos otros; por ejemplo, a una vida digna, a la salud, a un medio ambiente sano. No tener agua vulnera el derecho a la integridad personal, a la vida, a la información y a la participación (CEMDA et al., 2011). Sin embargo, persisten desigualdades sociales que dificultan el pleno ejercicio del derecho humano al agua (Castro, 2007; Langford y Khalfan, 2006). Entre ellos se encuentra la localización espacial, la estructura social population inhabits the south and southeast, $13 \%$ of the GDP is generated, and $69 \%$ of renewable water is found. That is, in the south and southeast there is more water, at the same time that there is important backwardness in terms of coverage of drinking water and drainage services (Nazar et al., 2010). In addition to this reality, there are differences inside the specific territorial divisions. Rural zones have drinking water coverage of $75.7 \%$, while in cities the percentage is 20 points higher (95.6\%) (SEMARNAT, 2012).

In its Article 14 bis 5, the National Waters Law establishes that public use of water for population centers has priority over others. However, concessions by CONAGUA do not always obey this norm and transnational capital (mining, agro-industry) tends to predominate over other interests (CEMDA et al., 2011). Privatization of natural resources has increased in recent years as a result of commercial liberalization and globalization (García, 2008; Bello, 2008). In face of this problem, international organisms and social organizations have promoted the recognition of the human right to water, which is defined by the International Covenant on Economic, Social and Cultural Rights (ICESCR) as the right that allows "making use of sufficient, healthy, acceptable, accessible and affordable water for personal and domestic use" (ICESCR cited in Domínguez et al., 2013:20). Such a right was ratified in México in 2012, with the modification of Article 4 of the Constitution to affirm that "every person has the right to access, availability and healthiness of water for personal and domestic consumption in a sufficient, healthy, acceptable and affordable manner" (in Domínguez et al., 2013:36).

The fulfillment of the human right to water is an indispensable requisite to attain many others; for example, a dignified life, health, a healthy environment. Not having access to water damages the right to personal integrity, life, information and participation (CEMDA et al., 2011). However, social differences persist which make the full exercise of the human right to water something difficult (Castro, 2007; Langford and Khalfan, 2006). Among them, some are spatial localization, social structure, as well as the interconnection of gender, class and ethnic group systems. The characterization of women and indigenous peoples as demographic variables or "vulnerable groups" has impeded for effective mechanisms to be designed to avoid gender and ethnic discrimination in the access 
y la interconexión de los sistemas de género, clase y etnia. La caracterización de mujeres y pueblos indígenas como variables demográficas o "grupos vulnerables" ha impedido que se diseñen mecanismos efectivos para evitar la discriminación de género y etnia en el acceso y el disfrute de agua suficiente, saludable y asequible (Rico, 2006).

Este artículo analiza el ejercicio del derecho humano al agua de las mujeres de Hidalgo en relación con cuatro variables: servicios de la vivienda, disponibilidad de agua, calidad de ésta y eficiencia en la gestión del recurso. Para tal fin se presenta el estudio de dos ejidos ubicados en dos regiones que conforman "las diagonales" de la pobreza del estado: el Valle del Mezquital (VM) y la Zona Otomí Tepehua (ZOT). La primera tiene una mayor contribución al PIB estatal, así como "menor incidencia de pobreza", mientras que la segunda es considerada la región más pobre del estado (Ángeles, 2011:36). Los resultados demuestran que no existe asociación directa entre crecimiento económico y ejercicio del derecho humano al agua, ya que es la ZOT la que presenta mejores desempeños en la mayoría de las variables analizadas.

\section{Propuesta conceptual: desarrollo, género y derecho humano al agua}

Desde su surgimiento, el concepto de desarrollo ha estado vinculado con una fuerte idea evolucionista que vincula a las sociedades de origen europeo con el progreso y a las culturas no occidentales con el atraso (Hernández y Suárez, 2004). Con la postguerra (1945) se asoció al desarrollo con el crecimiento económico, asunto que permitió la expansión del capitalismo en su fase industrial y la consolidación del liderazgo estadounidense en el mundo. Desde entonces se asume que el crecimiento económico trae consigo generación de empleos, intercambio comercial y bienestar social, es decir, es equivalente al progreso (Esteva, 1996).

La teoría de género ha cuestionado esta asociación. Las mujeres comenzaron a ser tema de discusión en la teoría del desarrollo de los años setenta del siglo pasado con el surgimiento de la propuesta Mujeres en el Desarrollo (MED). Ésta sugería que las mujeres habían sido excluidas de la modernización tecnológica, por lo que era necesario integrarlas a procesos de desarrollo (Boserup, 1970). Desde la teoría de Género en el Desarrollo (GED) se ha señalado que el problema no ha and enjoyment of sufficient, healthy and affordable water (Rico, 2006).

This article analyzes the exercise of the human right to water by women in Hidalgo, with regard to four variables: household services, water availability, water quality and efficiency of the resource's management. For that purpose, the study of two ejidos located in two regions that make up "the diagonals" of poverty in the state, are presented: Valle del Mezquital (VM) and Tepehua Otomí Zone (ZOT). The first has a higher contribution to the state GDP, as well as "lower incidence of poverty", while the second is considered the poorest region in the state (Ángeles, 2011:36). The results prove that there is no direct association between economic growth and the exercise of the human right to water, since it is ZOT which presents better performances in most of the variables analyzed.

\section{Conceptual proposal: development, gender and human right to water}

Since its origin, the concept of development has been linked to a strong evolutionist idea that connects societies of European origin with progress and nonWestern cultures with backwardness (Hernández and Suárez, 2004). With the post-war (1945), development was associated to economic growth, an issue that allowed the expansion of capitalism in its industrial phase and the consolidation of the United States' leadership in the world. Since then, it is assumed that economic growth brings with it employment generation, commercial exchange and social wellbeing, that is, that it is equivalent to progress (Esteva, 1996).

Gender theory has questioned this association. Women began to be a discussion theme in the development theory of the 1970s with the emergence of the Women in Development (WID) approach. This would suggest that women had been excluded from technological modernization, so it was necessary to integrate them into development processes (Boserup, 1970). From the perspective of the theory of Gender in Development (GID), it has been pointed out that the problem has not been women's exclusion, but rather their integration into the lowest levels of economy throughout the several centuries of European colonization and consolidation of the capitalist system (Benería and Sen, 1997). Unpaid domestic work and women's low income allow the reproduction of such a system and gender hierarchies. 
sido su exclusión, sino más bien su integración en los niveles más bajos de la economía a lo largo de varios siglos de colonización europea y afianzamiento del sistema capitalista (Benería y Sen, 1997). El trabajo doméstico no pagado y los bajos ingresos de las mujeres permiten la reproducción de dicho sistema y de las jerarquías de género. En otras palabras, GED analiza críticamente el papel que juegan tanto la dominación patriarcal como el sistema capitalista en la opresión de las mujeres (Kabeer, 1995). Desde esta perspectiva, la propuesta es un modelo de desarrollo capaz de reconocer los aportes del trabajo femenino a la economía, redistribuir la riqueza e impulsar el empoderamiento de las mujeres y los grupos más desfavorecidos de la sociedad (Moser, 1993; Young, 1997; Rai, 2002).

Este modelo sigue siendo una aspiración cuyas posibilidades de concreción se han visto fortalecidas por la ampliación de la cartera de derechos humanos de las mujeres, más allá del ejercicio de la democracia formal, para incluir el derecho a una vida digna y sin violencia a un medio ambiente sano y, por supuesto, al agua (IIDH, 2008). El PIDESC (citado en Langford y Khalfan, 2006:39) señala que los gobiernos firmantes deben atender los obstáculos que enfrentan "las mujeres, las personas con discapacidad, los niños y las niñas, los refugiados, los prisioneros y las comunidades nómadas" para acceder al agua. América Latina reporta pocos avances en este sentido, ya que los problemas hídricos han sido tratados de manera independiente de la desigualdad de género, "con su propia terminología, objetivos, prioridades e institucionalidad" (Rico, 2006:255).

Las mujeres rurales utilizan agua para actividades productivas (cultivos, crianza de animales, elaboración de artesanías), reproductivas (crianza de hijos e hijas, cuidado de ancianos y ancianas, preparación de alimentos, limpieza de la vivienda) y comunitarias (limpieza de zonas de uso común; por ejemplo, clínicas y escuelas). Cuando el agua escasea su carga de trabajo aumenta y su calidad de vida se deteriora (Carmona et al., 1998; Bonfil y Del Pont, 1999; REGEMA, 2006). Mujeres y niño/as de Chiapas dedican de dos a seis horas diarias para abastecerse de agua (Soares, 2006). El acarreo de agua conlleva problemas de salud (entre ellos, estrés y daños a la columna vertebral) y reduce las oportunidades de las mujeres de dedicarse a otras tareas (Rico, 2006). Las enfermedades ocasionadas por la mala calidad del
In other words, GID critically analyzes the role that both patriarchal domination and the capitalist system play in women's oppression (Kabeer, 1995). From this perspective, the proposal is a development model capable of recognizing the contributions of feminine work to the economy, redistributing wealth, and fostering the empowerment of women and the most disenfranchised groups in society (Moser, 1993; Young, 1997; Rai, 2002).

This model continues to be an aspiration whose possibilities for concretion have been strengthened by the expansion of the human rights portfolio for women, beyond the exercise of formal democracy, to include the right to a dignified life without violence in a healthy environment and, naturally, to water (IIDH, 2008). The ICESCR (cited in Langford and Khalfan, 2006:39) states that the signing governments should address the obstacles that "women, disabled people, children, refugees, prisoners and nomad communities" face to access water. Latin America reports few advances in this sense, since water problems have been treated independently from gender inequality, "with their own terminology, objectives, priorities and institutional operation" (Rico, 2006:255).

Rural women use water for productive (crops, animal breeding, handcraft manufacture), reproductive (bringing up children, caring for the elderly, food preparation, cleaning households) and community (cleaning zones of common use, such as clinics and schools) activities. When water is scarce their work load increases and their quality of life deteriorates (Carmona et al., 1998; Bonfil and Del Pont, 1999; REGEMA, 2006). Women and children from Chiapas devote two to six hours daily to obtain water (Soares, 2006). Water transport entails health problems (among them, stress and damages to the spinal column) and reduces women's opportunities to devote their time to other tasks (Rico, 2006). Illnesses caused by bad water quality also increase their workload because caring for sick people falls onto women (REGEMA, 2006). All these aspects, in addition to the disparities in infrastructure and the lack of quality in the piped water service (for example, intermittence), infringe on women's right to water.

\section{Methodology}

Information collection was done in four stages. The first consisted in a workshop carried out on 
agua también aumentan su carga de trabajo porque el cuidado de los enfermos/as recae en las mujeres (REGEMA, 2006). Todos estos aspectos, aunados a las disparidades de infraestructura y a la falta de la calidad en el servicio de agua entubada (por ejemplo, intermitencia), vulneran el derecho de las mujeres al agua.

\section{Metodología}

La recolección de información se realizó en cuatro etapas. La primera consistió en un taller realizado el 5 de agosto de 2011 con diversos representantes de instituciones gubernamentales, académicas y de la sociedad civil hidalguense. ${ }^{3}$ El objetivo fue realizar un primer acercamiento a la problemática del agua y su impacto en las mujeres. Al final se hizo un ejercicio de priorización para seleccionar dos áreas de estudio, bajo la idea de que las personas que asistieron al taller serían las principales usuarias de la información generada. Las zonas elegidas fueron el VM y la ZOT.

La segunda fase consistió en hacer entrevistas con autoridades y recorridos en las dos regiones, para elegir ejidos donde se pudieran hacer estudios de caso de mayor profundidad. Se escogieron dos: Colonia Veracruz (CV), del municipio de Mixquiahuala para el VM; y San Pedrito (SP), del municipio de Agua Blanca de Iturbide, para la ZOT (Figura 1).

La tercera etapa consistió en la aplicación de un cuestionario de preguntas cerradas en ambos ejidos que fueron respondidas únicamente por mujeres. En CV se seleccionó al azar a 40 (20 ejidatarias y 20 esposas de ejidatarios) a partir de la lista de titulares del ejido. En SP el cuestionario fue aplicado a $35 \mathrm{mu}-$ jeres: seis ejidatarias, una posesionaria y 19 esposas, cinco hijas, tres madres y una hermana de ejidatarios.

Para la cuarta y última etapa se realizó un muestreo indicativo de la calidad del agua durante la época de estiaje (octubre) en ambos ejidos. Entendemos por calidad del agua al conjunto de caracteres físicos, químicos y biológicos que se deben satisfacer con el fin de que el agua que se suministra sea segura (Solarte et al., 2006). De la contaminación por microorganismos la bacteriana es la más común, aunque también son frecuentes los virus, protozoarios y amebas (Ramírez et al., 2012). Es importante conocer la calidad microbiológica del agua por el riesgo asociado con la ingesta de agua contaminada con bacterias provenientes de heces humanas y animales (Bautista et al., 2013).
August 5, 2011, with various representatives from government, academia and civil society institutions in Hidalgo. ${ }^{3}$ The objective was to have the first approach to the water problematic and its impact on women. A prioritizing exercise was done at the end to select two study areas, under the idea that people who attended the workshop would be the main users of the information generated. The zones chosen were $\mathrm{VM}$ and ZOT.

The second stage consisted in having interviews with authorities and visits to the two regions, to select ejidos where case studies of greater depth could be performed. Two were chosen: Colonia Veracruz $(\mathrm{CV})$, in the municipality of Mixquiahuala for VM; and San Pedrito (SP), in the municipality of Agua Blanca de Iturbide, for ZOT (Figure 1).

The third stage consisted in applying a questionnaire of closed questions in both ejidos which were answered solely by women. In CV, 40 women (20 ejidatarias and 20 wives of ejidatarios) were randomly selected from the list of ejido titleholders. In SP, the questionnaire was applied to 35 women: six ejidatarias, one owner and 19 wives, five daughters, three mothers and one sister of ejidatarios.

For the fourth and last stage, a sampling indicative of the water quality during drought time (October) in both ejidos was performed. As water quality we contemplated the set of physical, chemical and biological characters that must be satisfied with the aim of safety in the water supplied (Solarte et al., 2006). Of contamination by microorganisms, bacterial is the most common, although viruses, protozoans and amoebas are also frequent (Ramírez et al., 2012). It is important to understand the microbiologic quality of water because of the risk associated with the intake of water contaminated with bacteria from human and animal feces (Bautista et al., 2013).

Ten samples in total were taken, five in each ejido. The sampling sites included sources of supply, delivery staff, storage deposits and distribution network. The samples were transported to the laboratory in sterilized containers for their biological analysis in triplicate. Additionally, coordinates of the site, elevation above sea level and water temperature were also recorded. The determinations considered were: total coliforms, fecal coliforms (NOM-112SSA1-1994), pH (norma NMX-AA-008SCFI-2000) and free chlorine (Table 1). The number of samples is 


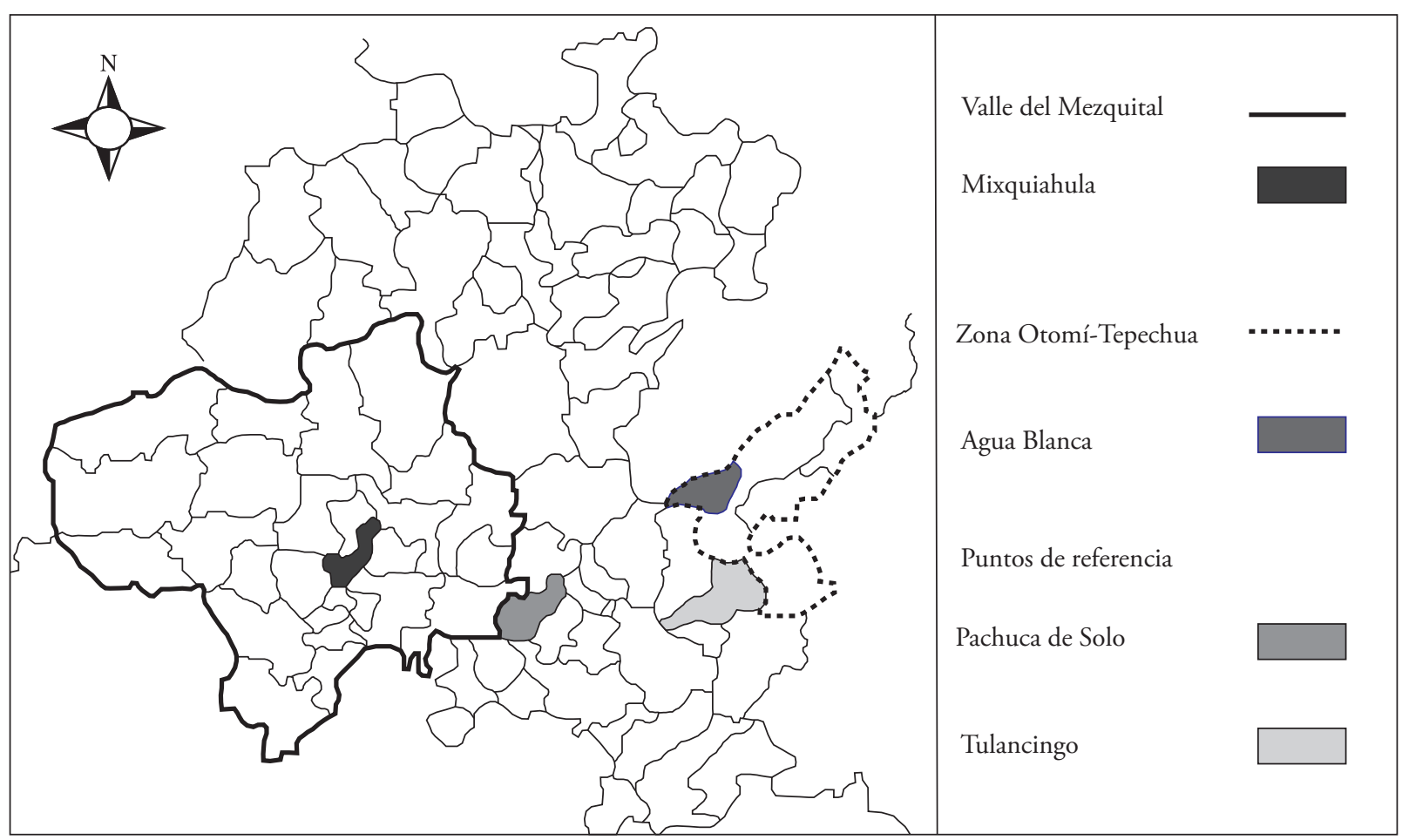

Figura 1. Valle del Mezquital y Zona Otomí Tepehua.

Figure 1. Valle del Mezquital and Otomí Tepehua Zone.

Se tomaron diez muestras en total, cinco en cada ejido. Los sitios de muestreo incluyeron fuentes de abastecimiento, repartidores, depósitos de almacenamiento y red de distribución. Las muestras fueron transportadas al laboratorio en frascos esterilizados para su análisis biológico por triplicado. Adicionalmente se tomaron las coordenadas del sitio, la altura sobre el nivel del mar y la temperatura del agua. Las determinaciones consideradas fueron: coliformes totales, coliformes fecales (NOM-112-SSA1-1994), pH (norma NMX-AA008SCFI-2000) y cloro libre (Cuadro 1). El número de muestras es reducido y los resultados pueden verse afectados por la hora de muestreo y la época del año. Aun así pensamos que, bajo un enfoque comparativo, el análisis de la calidad biológica del agua de ambos ejidos contribuye a establecer parámetros iniciales que pueden profundizarse en futuros estudios.

\section{ZONAS DE TRABAJO}

\section{Valle del Mezquital}

El VM constituye el área más grande del mundo con riego de aguas residuales (Ortega, 2011; Jiménez y Chávez, 2011). Dada su cercanía con reduced and the results can be affected by the time of sampling and time of year. Even so, we believe that under a comparative approach, the analysis of the biological quality of water in the ejidos contributes to establish initial parameters that can be further explored in future studies.

\section{WORK ZONES}

\section{Valle del Mezquital}

The VM constitutes the largest area in the world with residual water irrigation (Ortega, 2011; Jiménez and Chávez, 2011). Given its proximity to

Cuadro 1. Sitios de muestreo para análisis biológico del agua. Table 1. Sampling sites for biological analysis of water.

\begin{tabular}{ll}
\hline \multicolumn{1}{c}{ Colonia Veracruz } & \multicolumn{1}{c}{ San Pedrito } \\
\hline Manantial Tezontepec & SP, llave \\
CV, llave manantial Tezontepec & SP, tanque \\
Pozo 21 (uso doméstico) & Las Lajas, repartidor \\
CV, llave pozo 21 & Manantial El Yugo \\
Pozo 57 (riego) & Manantial Las Golondrinas \\
\hline
\end{tabular}


el Distrito Federal y el área metropolitana, fue por varias décadas el "abastecedor del mercado interno", proveyendo bienes básicos [maíz (Zea mays), frijol (Phaseolus vulgaris), alfalfa (Medicago sativa L.), hortalizas, tuna (Opuntia ficus-indica L.), higo (Ficus carica L.)] y mano de obra a la capital. Con la firma del Tratado de Libre Comercio se castigó la producción de hortalizas con aguas residuales para favorecer a "entidades con posibilidades competitivas, tanto para el mercado externo como el nacional”; por ejemplo, Sinaloa y Sonora (Robles, 2000:170). Actualmente, en el VM se riegan 99536 hectáreas pertenecientes a 51107 productores/as. Los principales cultivos son maíz, alfalfa y avena (generalmente de uso forrajero) y pocas hortalizas (Ortega, 2011; Jiménez y Chávez, 2011). Más de la mitad de la población del VM (61\%) vive de la agricultura de riego; la región genera $42 \%$ del PIB del estado (Cruz, 2011). Un número considerable de personas (500 000 habitantes de 294 localidades) están expuestas a agua contaminada por coliformes y metales pesados (Robles, 2000; Ortega, 2011; Jiménez y Chávez, 2011).

El municipio de Mixquiahuala se sitúa a una hora de la ciudad de Pachuca (Figura 1). Tiene un índice bajo de marginación (CONAPO, 2010). El ejido de CV fue fundado en 1936 con tierras pertenecientes a la hacienda Veracruz: "ahora tenemos lo que era de los hacendados", dijo un integrante del comisariado ejidal; 60 campesinos que trabajaban para la hacienda recibieron sus propias parcelas. En 1949, CV pasó a formar parte del distrito de riego 003-Tula (Robles 2000; Santillán 2011). Actualmente el ejido tiene 2093 habitantes (INEGI, 2010).

Las edades de las mujeres que respondieron el cuestionario en CV fluctúan entre los 41 y los 96 años, con 61 como promedio. Poco más de la mitad tiene responsabilidad conyugal (24), el resto son viudas y una es soltera. El promedio de escolaridad es de 4.25 ańos, encontrándose por debajo de la media estatal (8.1 años) y nacional (8.6 años) (INEGI 2010).

\section{Zona Otomí-Tepehua}

La mayor parte $(85 \%)$ de la población de la ZOT concentra sus actividades en el sector agropecuario, siendo los principales cultivos el café para la venta y el maíz, y el frijol para autoconsumo. En algunos municipios hay ganado bovino (lechero y de engorda),
Distrito Federal and the metropolitan area, during several decades it was the "supplier of the internal market", providing basic goods [maize (Zea mays), bean (Phaseolus vulgaris), alfalfa (Medicago sativa L.), vegetables, prickly pear (Opuntia ficus-indica L.), fig (Ficus carica L.)] and workforce for the capital. With the signing of the Free Trade Agreement, the production of vegetables with residual waters was damaged in favor of "entities with competitive possibilities, both for the external and the national market"; for example, Sinaloa and Sonora (Robles, 2000:170). Currently, 99536 hectares are irrigated in VM, which belong to 51107 producers. The principal crops are maize, alfalfa and oats (generally for use as fodder) and few vegetables (Ortega, 2011; Jiménez and Chávez, 2011). More than half of the population of VM (61\%) lives off irrigation agriculture; the region generates $42 \%$ of the state GDP (Cruz, 2011). A considerable number of people (500 000 inhabitants from 294 localities) are exposed to water contaminated by coliforms and heavy metals (Robles, 2000; Ortega, 2011; Jiménez y Chávez, 2011).

The municipality of Mixquiahuala is located one hour from the city of Pachuca (Figure 1). There is a low index of marginalization (CONAPO, 2010). The ejido of CV was founded in 1936 with lands that belonged to Hacienda Veracruz: "now we have what used to belong to hacienda owners", stated a member of the ejido commissary; 60 peasants who worked for the hacienda received their own plots of land. In 1949, CV became part of irrigation district 003-Tula (Robles 2000; Santillán 2011). Currently the ejido has 2093 inhabitants (INEGI, 2010).

The ages of women who responded to the CV questionnaire range from 41 to 96 years, with 61 as average. Little more than half are married (24), the rest are widows and one is single. The schooling average is 4.25 years, which is below the state ( 8.1 years) and national (8.6 years) average (INEGI 2010).

\section{The Otomí-Tepehua Zone}

The largest part $(85 \%)$ of the ZOT population concentrates its activities in the agricultural and livestock sector, with the principal crops being coffee for sale and maize and bean for auto consumption. In some municipalities there is cattle livestock (for milk and for fattening), irrigation fodder crops, sugar cane, 
cultivos forrajeros de riego, caña de azúcar, manzana y magueyeras (Vargas, 2011; OEIDRUS, 2014).

Las áreas boscosas de la ZOT son considerables en cantidad. En ella se encuentran al menos tres tipos de vegetación: bosque mesófilo de montańa, bosque tropical perennifolio y bosque de coníferas y encinos (Villavicencio et al., 2010). Alcántara y Luna (citados en Villavicencio y Pérez, 2005:4) reportan una lista florística de 452 especies, como evidencia la biodiversidad existente. Sin embargo, uno de los problemas más severos de la región es la deforestación causada por la ganaderización y el avance de pastizales.

El municipio de Agua Blanca de Iturbide se sitúa a una hora de la ciudad de Tulancingo (Figura 1). Tiene un índice medio de marginación (CONAPO, 2010). Presenta dos tipos de vegetación: bosque de clima templado frío o bosque de pino-encino y bosque mesófilo de montaña. Hasta 2006 se tenían registradas 4406 hectáreas de superficie de uso forestal, así como 30 cuerpos de agua (OEIDRUS, 2014). Alrededor de 230 predios del municipio se encuentran bajo manejo forestal (Vázquez y Muñoz, 2011). Uno de ellos es SP, ejido creado por dotación presidencial en 1928. En 1996, PROCEDE entregó un certificado con la leyenda "uso común" mediante la cual se otorgó un porcentaje $(2.85 \%)$ de tierras ejidales en copropiedad a 78 ejidatarios/as. El ejido consta de dos localidades: "San Pedrito Potrerillos" (136 habitantes) y "San Pedrito" (179 habitantes) (INEGI, 2010). Su principal actividad es el aprovechamiento forestal de madera en rollo, principalmente pino, especie de mayor valor comercial. También existen pequeñas superficies destinadas a la producción agrícola, que son consideradas pequeña propiedad y tienen una extensión de entre 1250 y $15000 \mathrm{~m}^{2}$.

Las edades de las mujeres de SP que respondieron el cuestionario van desde los 21 hasta los 82 años, con un promedio de 43. Poco más de la mitad (23) tiene responsabilidad conyugal. El resto son viudas (seis), solteras (cinco) y una divorciada. Su promedio de escolaridad es de cinco años cursados de primaria, encontrándose por debajo de la media estatal (8.1 años) y de la media nacional (8.6 ańos) (INEGI, 2010).

\section{Problemática del agua en las DOS REGIONES ESTUDIADAS}

Los y las participantes del taller identificaron dos tipos de problemas con el agua: 1) de distribución; y 2) de calidad. El Cuadro 2 muestra que ambos son apple and maguey (Vargas, 2011; OEIDRUS, 2014).

Forest areas in the ZOT are considerable in numbers. In this zone there are at least three types of vegetation: mountainous mesophyll forest, evergreen tropical forest and conifer and live oak forest (Villavicencio et al., 2010). Alcántara and Luna (cited in Villavicencio and Pérez, 2005:4) report a flower list of 452 species, as evidence of the existing biodiversity. However, one of the more severe problems in the region is deforestation caused by increasing livestock production, and the advance of grasslands.

The municipality of Agua Blanca de Iturbide is located one hour from the city of Tulancingo (Figure 1). It has a medium index of marginalization (CONAPO, 2010). It presents two types of vegetation: forest of temperate cold climate or pinelive oak forest, and mountain mesophyll forest. Up until 2006, there were 4406 hectares of forest use recorded, as well as 30 water bodies (OEIDRUS, 2014). Around 230 plots in the municipality are under forest management (Vázquez and Muñoz, 2011). One of them is SP, an ejido created by presidential cession in 1928. In 1996, PROCEDE delivered a certificate with the inscription of "common use" through which a percentage $(2.85$ $\%)$ of ejido land was granted in co-ownership to 78 ejidatarios. The ejido has two localities: "San Pedrito Potrerillos" (136 habitantes) and "San Pedrito" (179 inhabitants) (INEGI, 2010). Their main activity is forest use for roll wood, primarily pine, the species of highest commercial value. There are also small surfaces destined to agricultural production, which are considered small properties and have an extension of between 1250 and $15000 \mathrm{~m}^{2}$.

The ages of SP women who responded the questionnaire range from 21 to 82 years, with an average of 42 . Slightly more than half (23) are married. The rest are widows (six), single (five) and one divorcee. Their average schooling is five years of primary school, and they are below the state (8.1 years) and national (8.6 years) averages (INEGI, 2010).

\section{WATER PROBLEMS IN THE TWO REGIONS STUDIED}

Participants in the workshop identified two types of problems with water: 1) distribution, and 2) quality. Table 2 shows that both are more pressing in 
más apremiantes en el VM, a pesar de sus mejores índices económicos (aportación al PIB) y sociales (grado de marginación).

En el VM se mencionaron problemas de distribución (puntos 1 y 2 del Cuadro 2), seguidos de la calidad (puntos 3 y 4 del mismo cuadro). Se habló de empresas, corredores industriales, balnearios y autolavados que "gastan mucha agua", de regiones donde las partes bajas tienen riego y las altas "sufren la escasez de agua”. En relación con la falta de calidad, los principales contaminantes son desechos industriales, una refinería, una termoeléctrica, la agricultura de riego con aguas residuales, y los fraccionamientos; es decir, todo lo que generalmente se asocia con progreso y desarrollo. Según los y las participantes del taller, algunos de los contaminantes son "precursores de cáncer" o "causantes de demencia".

Los y las participantes también señalaron que en el VM hay un aumento en el gasto hídrico, debido a la perforación indiscriminada de pozos. También existe infraestructura deficiente para el agua de riego y el agua potable, incluyendo la ausencia de plantas de tratamiento. Insistieron en que el desarrollo industrial y agrícola no sería un problema si se respetara la legislación ambiental.

Los problemas de la ZOT tienen más que ver con la infraestructura disponible para obtener y distribuir agua
$\mathrm{VM}$, in spite of its better economic (contribution to GDP) and social (degree of marginalization) indexes.

In $\mathrm{VM}$, distribution problems were mentioned (points 1 and 2 in Table 2), followed by those in quality (points 3 and 4 of the same table). There was a discussion about companies, industrial corridors, resorts and car washes that "waste too much water", of regions where the low parts have irrigation and the high "suffer from water scarcity". With regard to the lack of quality, the main contaminants are industrial wastes, a refinery, a thermoelectric plant, irrigation agriculture with residual waters, and residential developments; that is, everything that is generally associated with progress and development. According to the workshop participants, some of the contaminants are "cancer precursors" or "cause dementia".

Participants also pointed out that in VM there is an increase in water use due to the indiscriminate perforation of wells. There is also deficient infrastructure for irrigation and drinking water, including the absence of treatment plants. They insisted in that industrial and agricultural development would not be a problem if environmental legislation were to be respected.

The problems in ZOT have more to do with the infrastructure available to obtain and distribute water from springs, main source of supply. This situation

Cuadro 2. Problemática del agua.

Table 2. Water problems.

\begin{tabular}{|c|c|}
\hline Valle del Mezquital & Zona Otomí-Tepehua \\
\hline $\begin{array}{l}\text { Escasez de agua potable para actividades urbanas. } \\
\text { Problemas de distribución de agua potable. } \\
\text { Calidad deficiente del agua potable. } \\
\text { Falta de plantas de tratamiento de agua. } \\
\text { Falta de información para el uso seguro de agua potable. } \\
\text { Riego agrícola con aguas residuales. } \\
\text { Pérdidas de agua por evaporación en riego. } \\
\text { Infraestructura inadecuada para conducir el agua de riego. } \\
\text { Infraestructura obsoleta para conducción de agua potable. } \\
\text { Contaminación en zona industria Tula-Tepeji (especial anilinas } \\
\text { que van al rio Tula, precursoras de cáncer; mientras que los meta- } \\
\text { les pesados producen demencia). } \\
\text { Contaminación de hidrocarburos por la refinería Miguel Hidalgo } \\
\text { que van al rio Tula (a pesar de tener planta tratadora). } \\
\text { Contaminación de rio por termoeléctrica. } \\
\text { Permisos indiscriminados de fraccionamientos. } \\
\text { Perforación indiscriminada de pozos. } \\
\text { Desperdicio de agua (en actividades domésticas). } \\
\text { Contaminación del agua (la que llega a la agricultura). } \\
\text { Contaminación de mantos freáticos. } \\
\text { Contaminación de agua por actividades urbanas }\end{array}$ & $\begin{array}{l}\text { Falta de infraestructura y sistemas ineficientes para la conduc- } \\
\text { ción de agua desde manantiales. } \\
\text { Acarreo de agua hasta seis horas. } \\
\text { Lavado de ropa en manantiales. } \\
\text { Disminución de la disponibilidad de agua por la deforestación. } \\
\text { Contaminación de fuentes de agua con desechos sólidos. } \\
\text { Falta de coordinación en los tres niveles de gobierno. } \\
\text { Poder que satisface intereses personales. }\end{array}$ \\
\hline
\end{tabular}


de los manantiales, principal fuente de abastecimiento. Esta situación ocasiona que no se tenga agua en casa, que haya que acarrearla o lavar en manantiales. Los problemas de contaminación están más asociados con desechos sólidos, es decir, con un manejo ineficiente de la basura. Los y las participantes del taller atribuyeron esta situación a la deforestación, la ineficiencia gubernamental y el uso patrimonial del poder que obstaculiza la gestión democrática de los recursos naturales.

\section{Servicios de agua para uso doméstico en los dos ejidos}

El ejido de CV tiene tres fuentes de agua: el canal proveniente del manantial de Tezontepec (que abastece a una tercera parte de la población), el pozo 21 (que abastece a dos terceras partes) y el 57 (utilizado para riego agrícola y ocasionalmente para uso doméstico). Por su parte, las fuentes de agua en SP son varios manantiales que abastecen las cascadas de Las Golondrinas, El Yugo y La Laja. Éstas, a su vez, conforman los ríos Golondrina, Yugo, Sabanilla, Agua Bendita, Jabalín, Potrerillos, Meco y Chiflón (Cuadro 3).

El sistema de distribución en CV abastece solo a su propia población, mientras que el de SP abastece a las dos localidades de SP (San Pedrito Potrerillos y San Pedrito), a la cabecera municipal y a varias comunidades aguas abajo. Algunas no pertenecen al municipio de Agua Blanca, sino a Huasca de Ocampo (Cuadro 3). causes for there to be a lack of water in the households, for it having to be carried or for they to be forced to wash in the springs. Contamination problems are associated more with solid wastes, that is, with an inefficient management of garbage. Workshop participants attributed this situation to deforestation, government inefficiency and the patrimonial use of power, which hinders the democratic management of natural resources.

\section{Water services for domestic use in the two ejidos}

The CV ejido has three sources of water: a channel from the spring in Tezontepec (which supplies a third of the population), Well 21 (which supplies two thirds) and Well 57 (used for agricultural irrigation and occasionally for domestic use). In their part, the sources of water in SP are several springs supplied by the falls Las Golondrinas El Yugo and La Laja. These, in their turn, make up the rivers Golondrina, Yugo, Sabanilla, Agua Bendita, Jabalín, Potrerillos, Meco and Chiflón (Table 3).

The distribution system in CV supplies only its own population, while the one in SP supplies the two localities in SP (San Pedrito Potrerillos and San Pedrito), the municipal township, and several communities downstream. Some don't belong to the municipality of Agua Blanca, but rather to Huasca de Ocampo (Table 3).

Most of the households in CV and SP receive

Cuadro 3. Fuentes de agua y sistemas de distribución.

Table 3. Sources of water and distribution systems.

\begin{tabular}{|c|c|c|}
\hline & Colonia Veracruz & San Pedrito \\
\hline Fuentes de abastecimiento & $\begin{array}{l}\text { - Pozo } 21 \text { (uso doméstico, } 2 / 3 \text { partes de la } \\
\text { población aproximadamente) } \\
\text { - Pozo } 57 \text { (riego) } \\
\text { - Canal proveniente de Tezontepec (uso do- } \\
\text { méstico, } 1 / 3 \text { parte de la población) }\end{array}$ & $\begin{array}{l}\text { Cascadas: las Golondrinas, el Yugo y la Laja } \\
\text { Ríos: Golondrina, Yugo, Sabanilla, Agua Bendita, Jabalín, } \\
\text { Potrerillos, Meco y Chiflón }\end{array}$ \\
\hline Sistemas de distribución & Abasto al ejido & $\begin{array}{l}\text { - Abasto al ejido y a la colonia (San Pedrito Potrerillos y } \\
\text { San Pedrito } \\
\text { - Abasto a la cabecera municipal (Agua Blanca) } \\
\text { - Abasto a otras comunidades aguas abajo: } \\
\text { a) Tubería directa de los repartidores o manantiales: SP, } \\
\text { Agua Blanca cabecera, Loma Ancha, Buena Vista, Ma- } \\
\text { gueyes Verdes y Loma Bonita } \\
\text { b) Tubería secundaria (toma de agua de tubería de otra } \\
\text { comunidad): La Vega, Acatlán, San Cornelio Xóchitl y } \\
\text { Peńa de Agua }\end{array}$ \\
\hline
\end{tabular}


Cuadro 4. Medios para proveerse de agua para uso doméstico.

Table 4. Means for women to supply themselves with water for domestic use.

\begin{tabular}{lcccc}
\hline Medio & CV frecuencia & CV $\%$ & SP frecuencia & SP \% \\
\hline Tubería & 40 & 100 & 26 & 74 \\
Manguera & 0 & 0 & 3 & 9 \\
Vehículo & 0 & 0 & 2 & 6 \\
Otras & 0 & 0 & 4 & 11 \\
\hline Total & 40 & 100 & 35 & 100 \\
\hline
\end{tabular}

La mayoría de las viviendas de CV y SP reciben agua por tubería, aunque existe una diferencia importante entre ambas, ya que una cuarta parte de las de SP no forman parte de la red (Cuadro 4).

\section{Disponibilidad}

A pesar de que la mayoría de las viviendas reciben agua por tubería, en los dos ejidos se reporta un problema de escasez. Todas las mujeres de CV y $60 \%$ de las de SP indicaron padecerla, siendo mayo el mes más crítico. Muchas comunidades rurales del país presentan un problema de intermitencia e irregularidad en el servicio, además de falta de control de calidad en el recurso, particularmente para consumo humano (REGEMA, 2006; Salazar et al., 2012). Esto coincide con lo señalado por la Organización Panamericana de la Salud (citada en Rico: 2006:260): en algunos países, cerca de $95 \%$ de los sistemas de abastecimiento tienen problemas de intermitencia. Esta situación representa un importante obstáculo para el pleno ejercicio del derecho humano al agua.

La principal razón de la falta de agua en $\mathrm{CV}$ no es la escasez física, sino más bien que el pozo 21 (de uso doméstico) no funciona. Hay un problema de morosidad (60\% de los usuarios aproximadamente) y, por lo tanto, una importante deuda de energía eléctrica. Cuando el pozo 21 está fuera de funcionamiento se enciende el 57 (de riego), cuyo uso es limitado porque no tiene tubería conectada a la red de distribución. La gente toma agua de este pozo y del canal para diversas necesidades que no involucran consumo humano, el cual es cubierto con agua de garrafón. En SP el desabasto es menor, aunque las autoridades manifestaron que el volumen de las escorrentías se reduce entre abril y junio. Los y las habitantes de comunidades aguas abajo reportaron escasez atribuible al estiaje y ruptura o perforación de tuberías. piped water, although there is an important difference between both, since a fourth of those in SP are not part of the network (Table 4).

\section{Availability}

Although most of the households receive piped water, in the two ejidos a problem of scarcity is reported. All the women in CV and $60 \%$ of those in SP indicated suffering from it, with May being the most critical month. Many rural communities present a problem of intermittence and irregularity in the service, in addition to lack of control of the quality of the resource, particularly for human consumption (REGEMA, 2006; Salazar et al., 2012). This coincides with what is pointed out by the Pan-American Health Organization (cited in Rico, 2006:260): in some countries, close to $95 \%$ of the supply systems have problems of intermittence. This situation represents an important obstacle for the full exercise of the human right to water.

The main reason for the lack of water in $\mathrm{CV}$ is not physical scarcity, but rather that Well 21 (of domestic use) does not work. There is a problem of delay in payment (60\% of the users, approximately) and, therefore, an important debt in electric energy. When Well 21 is not functioning, Well 57 (for irrigation) turns on, but its use is limited because it does not have piping connected to the distribution network. People take water from that well and the channel for various needs that do not involve human consumption, which is covered with bottled water. In SP the lack of supply is lower, although the authorities manifest that the volume of the runoff is reduced between April and June. Inhabitants from the communities downstream report scarcity attributable to low water level and rupture or perforation of pipes. 


\section{Calidad}

El término de agua "potable" es engańoso porque puede referirse a situaciones donde el agua nunca ha sido potabilizada. Por ejemplo, en muchas comunidades abastecidas por manantiales, los comités que administran el agua se llaman "comité de agua potable", más por tradición que por referirse al tratamiento del agua (García, 2012). En algunos casos, la que sí ha sido potabilizada se transporta a través de redes de conducción que no reciben mantenimiento, por lo que en su recorrido vuelven a contaminarse. Mucha gente utiliza sistemas de purificación doméstica o incluso compra agua para consumo humano (Amemiya, 2006). Esta situación representa un obstáculo para el ejercicio del derecho al agua, el cual estipula que ésta tiene que ser "suficiente, salubre, aceptable, accesible y asequible para el uso personal y doméstico" (PIDESC citado en Domínguez et al., 2013:20), es decir, segura para consumo humano.

En el momento de la visita a campo, el pozo 21 de CV tenía instalado un clorador automático que había dejado de funcionar y no existía ninguna medida alternativa para purificar el agua. En cambio, en SP se constató que anteriormente se utilizaba un sistema de cloración directa en depósitos de almacenamiento, el cual recientemente fue remplazado por plata coloidal. Los insumos son proporcionados por el gobierno municipal y administrados por el comité de agua de la localidad, en el entendido de que el municipio recibe agua de SP y debe contribuir a su buen estado.

Las diferencias de infraestructura entre ambos ejidos coinciden con las opiniones de las mujeres. En $\mathrm{CV}$, sólo $48 \%$ dijo que el agua que reciben en casa es de calidad, contra $100 \%$ de las mujeres de SP. Destaca el hecho de que la zona más contaminada no tenga un sistema funcional de tratamiento de agua y que la población tenga que consumir agua de garrafón. La encuesta indicó que la mayoría de las mujeres (34 de 40) de CV compran agua de garrafón para tomar. La mayoría (92.5\%) compra entre uno y cuatro, con un gasto promedio de 27 pesos semanales por familia.

Los resultados de laboratorio reportaron la presencia de contaminación biológica (principalmente coliformes totales) en CV a excepción del pozo 57. La llave del manantial Tezontepec además tiene coliformes fecales. A pesar de que esta agua es clorada en dos sitios durante su recorrido, su transecto por

\section{Quality}

The term "drinking" water is deceitful because it can refer to situations where water has never been made to be drinkable. For example, in many communities supplied by springs, the committees that manage water are called "drinking water committee", more as a result of tradition than referring to water treatment (García, 2012). In some cases, the water that has been made drinkable is transported through conduction networks that do not receive maintenance, so that in its transport it becomes contaminated again. Many people use domestic purification systems or even purchase water for human consumption (Amemiya, 2006). This situation represents an obstacle for the exercise of the right to water, which stipulates that it should be "sufficient, healthy, acceptable, accessible and affordable for personal and domestic use" (ICESCR cited in Domínguez et al., 2013:20); that is, safe for human consumption.

At the time of the field visit, Well 21 in CV had an automatic chlorinator installed, which had ceased to function, and there was no alternative means to purify the water. Instead, in SP it was confirmed that a direct chlorination system previously was used in storage deposits, which had been recently replaced with colloidal silver. The inputs are provided by the municipal government and managed by the water committee in the locality, under the assumption that the municipality receives water from SP and must contribute to its good state.

The differences in infrastructure between both ejidos coincide with the opinions of women. In CV, only $48 \%$ said that water they receive at home has quality, against $100 \%$ of the women in SP. The fact that the most contaminated zone does not have a functional system for water treatment stands out and also that the population has to consume bottled water. The survey indicated that most of the women (34 out of 40) in CV purchase water bottles for drinking. Most (92.5 \%) purchase between one and four, with an average expense of 27 pesos weekly per family.

Results from the lab reported the presence of biological contamination (primarily total coliforms) in CV, with the exception of Well 57. The tap of the Tezontepec spring also has fecal coliforms. Although this water is chlorinated in two sites during its transport, travelling through channels in the open 
Cuadro 5. Contenidos de coliformes totales y fecales, $\mathrm{pH}$ y cloro libre (SP)

Table 5. Contents of total and fecal coliforms, $\mathrm{pH}$ and free chlorine (CV).

\begin{tabular}{|c|c|c|c|c|c|c|c|}
\hline \multirow{2}{*}{ Sitio de muestreo } & \multirow{2}{*}{$\begin{array}{c}\text { Altura } \\
(\mathrm{msnm})\end{array}$} & \multicolumn{2}{|c|}{ Coordenadas } & $\begin{array}{c}\text { Coliformes } \\
\text { totales }\end{array}$ & $\begin{array}{c}\text { Coliformes } \\
\text { fecales }\end{array}$ & \multirow{2}{*}{$\mathrm{pH}$} & \multirow{2}{*}{$\begin{array}{c}\text { Cloro libre } \\
\left(\mathrm{mg} \mathrm{L}^{-1}\right)\end{array}$} \\
\hline & & $\mathrm{LN}$ & LW & \multicolumn{2}{|c|}{$\mathrm{NMP} / 100 \mathrm{~mL}$} & & \\
\hline Manantial Tezontepec & 1954 & $20^{\circ} 11^{\prime} 33.70^{\prime \prime}$ & $99^{\circ} 16^{\prime} 18.10^{\prime \prime}$ & 2.2 & $<1.1$ & 7.51 & ND \\
\hline Llave manantial Tezontepec & 1927 & $20^{\circ} 15^{\prime} 27.70^{\prime \prime}$ & $99^{\circ} 08^{\prime} 24.30^{\prime \prime}$ & 12.0 & 2.2 & 7.37 & ND \\
\hline Pozo 21 & 2001 & $20^{\circ} 15^{\prime} 47.80^{\prime \prime}$ & $99^{\circ} 08^{\prime} 42.80^{\prime \prime}$ & 5.0 & $<1.1$ & 7.24 & ND \\
\hline Llave pozo 21 & 1943 & $20^{\circ} 16^{\prime} 07.90^{\prime \prime}$ & $99^{\circ} 14^{\prime} 08.48^{\prime \prime}$ & 2.1 & $<1.1$ & 7.37 & ND \\
\hline Pozo 57 & 2479 & $19^{\circ} 25^{\prime} 15.59^{\prime \prime}$ & $99 \circ 44^{\prime} 16.53 ”$ & $<1.1$ & $<1.1$ & 7.75 & ND \\
\hline
\end{tabular}

ND: no detectable. Temperaturas del agua entre $11-140{ }^{\circ} \mathrm{C}$. Referencia conforme a norma: LÍMITES MAXIMOS. Organismos coliformes totales <1.1 NMP/100 mL. Organismos coliformes fecales <1.1 NMP/100 mL. pH 6.5-8.5. Cloro libre 0.1 mg/L. • ND: non detectable. Temperature of water between $11-140{ }^{\circ} \mathrm{C}$. Reference in compliance to the norm: MAXIMUM LIMITS. Total coliform organisms $<1.1 \mathrm{NMP} / 100 \mathrm{~mL}$. Fecal coliform organisms $<1.1 \mathrm{NMP} / 100 \mathrm{~mL}$. pH 6.5-8.5. Free chlorine 0.1mg/L.

canales al aire libre la expone a todo tipo de animales, posible mezcla con aguas residuales y otros contaminantes de los canales mismos. El pozo 57 es el único que está dentro de los límites permitidos; resulta paradójico que sea utilizado para riego y solo ocasionalmente para uso doméstico. Los valores de $\mathrm{pH}$ están conforme a norma. En ninguno de los casos fue detectado cloro, pese a que en el agua proveniente de Tezontepec sí se utiliza (Cuadro 5).

En SP también se detectó la presencia de coliformes totales en la mayoría de las muestras, debido a que el agua se transporta por canales sin revestir y expuestos a la intemperie y a la fauna silvestre. Sin embargo, en ningún caso la contaminación es tan alta como la del manantial de Tezontepec. El análisis del agua de llave de SP muestra que el tratamiento con plata coloidal es exitoso, a diferencia del agua de llave del manantial de Tezontepec, en la cual se encontraron coliformes fecales y totales (Cuadro 6).

\section{Eficiencia en la gestión del agua}

Las comunidades rurales del país tienen formas organizativas propias que les han permitido abastecerse de agua a lo largo de los siglos. Esto fortalece su capacidad para resolver problemas mediante normas y acuerdos sustentados en la acción colectiva (Wade, 1988; Agarwal y Narain, 1991; Ostrom, 2000). Sin embargo, el gobierno no ha favorecido la autogestión comunitaria. Las organizaciones para la gestión del agua de uso doméstico carecen de reconocimiento jurídico; el municipio o un organismo operador son los que deben, jurídicamente, administrar expose it to all sorts of animals, to possible mixing with residual waters, and other contaminants in the channels themselves. Well 57 is the only one that is inside the allowed limits; it is paradoxical that it is used for irrigation and only occasionally for domestic use. The $\mathrm{pH}$ values are in agreement with the norms. Chlorine was not detected in any of the cases, in spite of its use in the water from Tezontepec (Table 5).

In SP, the presence of total coliforms was also detected in most of the samples, because the water is transported in channels without lining, and exposed to the open and to wild animals. However, in no case is contamination as high as in the Tezontepec spring. The water analysis from the tap in SP shows that treatment with colloidal silver is successful, in contrast with the spring water from Tezontepec, where fecal and total coliforms were found (Table 6).

\section{Efficiency in water management}

Rural communities in the country have organizational forms of their own that have allowed them to have access to water throughout the centuries. This strengthens their capacity to solve problems through norms and agreements sustained in collective action (Wade, 1988; Agarwal and Narain, 1991; Ostrom, 2000). However, the government has not favored community auto-management. Water management organizations for domestic use lack legal recognition; the municipality or operating organism are the ones that should, legally, manage the domestic water supply systems (Aboites, 1998; Galindo and Palerm, 2012). 
Cuadro 6. Contenidos de coliformes totales y fecales, $\mathrm{pH}$ y cloro libre (SP). Table 6. Contents of total and fecal coliforms, $\mathrm{pH}$ and free chlorine (SP).

\begin{tabular}{|c|c|c|c|c|c|c|c|}
\hline \multirow{2}{*}{ Sitio de muestreo } & \multirow{2}{*}{$\begin{array}{c}\text { Altura } \\
(\mathrm{msnm})\end{array}$} & \multicolumn{2}{|c|}{ Coordenadas } & Coliformes & Coliformes & \multirow{2}{*}{$\mathrm{pH}$} & \multirow{2}{*}{$\begin{array}{c}\text { Cloro libre } \\
\left(\mathrm{mg} \mathrm{L}^{-1}\right)\end{array}$} \\
\hline & & $\mathrm{LN}$ & LW & \multicolumn{2}{|c|}{$\mathrm{NMP} / 100 \mathrm{~mL}$} & & \\
\hline SP, llave & 2214 & $20^{\circ} 22^{\prime} 05.3^{\prime \prime}$ & $98^{\circ} 20^{\prime} 44.0^{\prime \prime}$ & $<1.1$ & $<1.1$ & 7.46 & ND \\
\hline SP, tanque & 2272 & $20^{\circ} 21^{\prime} 54.6^{\prime \prime}$ & $98^{\circ} 20^{\prime} 22.2^{\prime \prime}$ & 5.0 & $<1.1$ & 7.38 & ND \\
\hline Las Lajas & 2277 & $20^{\circ} 21^{\prime} 42.8^{\prime \prime}$ & $98^{\circ} 19^{\prime} 58.6^{\prime \prime}$ & 5.0 & $<1.1$ & 7.38 & ND \\
\hline El Yugo & 2267 & $20^{\circ} 22^{\prime} 04.3^{\prime \prime}$ & $98^{\circ} 19^{\prime} 51.0^{\prime \prime}$ & 6.0 & $<1.1$ & 6.79 & ND \\
\hline Las Golondrinas & 1864 & $20^{\circ} 22^{\prime} 40.8^{\prime \prime}$ & $98^{\circ} 20^{\prime} 09.0^{\prime \prime}$ & 5.1 & 5.1 & 7.62 & ND \\
\hline
\end{tabular}

ND: no detectable. Temperaturas del agua entre 11-140 ${ }^{\circ} \mathrm{C}$. Referencia conforme a norma: Límites MAXIMOS. Organismos coliformes totales <1.1 NMP/100 mL. Organismos coliformes fecales <1.1 NMP/100 mL. pH 6.5-8.5. Cloro libre 0.1mg/L. • ND: non detectable. Temperature of water between $11-140{ }^{\circ} \mathrm{C}$. Reference in compliance to the norm: MAXIMUM LIMITS. Total coliform organisms $<1.1 \mathrm{NMP} / 100 \mathrm{~mL}$. Fecal coliform organisms <1.1 NMP/100 mL. pH 6.5-8.5. Free chlorine 0.1mg/L.

los sistemas de abasto de agua doméstica (Aboites, 1998; Galindo y Palerm, 2012).

La administración del pozo 21 en CV inicialmente estuvo a cargo del Sistema de Agua Potable y Alcantarillado del Municipio de Mixquiahuala (SAPAMM), el cual ayudó a gestionarlo. Posteriormente pasó a ser administrado por un comité de agua del ejido, debido a que la población de CV no reconoció la municipalización del servicio. El pozo 57 es independiente de este sistema puesto que está destinado al riego. Es administrado por un comité de productores que accede a proporcionar agua de uso doméstico cuando no se tiene necesidad de riego, con la limitante de que no está conectado a la red de tubería. Finalmente, el manantial de Tezontepec abastece a la población que vive cerca del canal, pero los y las usuarias reconocen que la calidad del agua es dudosa, por lo que no la usan para consumo humano. Esta agua sólo es utilizada para lavar ropa, regar plantas, alimentar animales, etcétera.

Como ya se dijo arriba, durante nuestra estancia en campo el pozo 21 estaba fuera de funcionamiento debido a la morosidad y el adeudo de electricidad. El SAPAMM conoce las dificultades que actualmente se viven con el pozo e incluso ha intervenido en otras ocasiones para repararlo. Dado que los recursos económicos para hacerlo se deben recabar y manejar localmente, ya está más renuente a hacerlo (Cuadro 7).

La situación en SP es muy distinta. El ejido tiene un plan de manejo forestal que ha promovido el aprovechamiento maderero y el pago por servicios ambientales. Éste incluye entre sus normas la prohibición de basura y el cuidado del agua. Además, en el
Management of Well 21 in CV was initially in charge of the Drinking Water and Sewage System of the Municipality of Mixquiahuala (Sistema de Agua Potable y Alcantarillado del Municipio de Mixquiahuala, SAPAMM), which helped to handle it. Later, it began to be managed by an ejido water committee, because the population of $\mathrm{CV}$ did not admit the municipal management of the service. Well 57 is independent of this system because it is destined to irrigation. It is managed by a committee of producers who agree to provide water for domestic use when there is no need for irrigation, with the limitation that it is not connected to the pipe network. Finally, the Tezontepec spring supplies the population that lives near the channel, but the users recognize that the quality of the water is uncertain, so they don't use it for human consumption. This water is only used to wash clothes, water plants, feed animals, etc.

As was mentioned before, during our stay in the field, Well 21 was not functioning due to delay in payment and electric power debt. The SAPAMM understands the difficulties that are currently experienced with the well and it has even intervened on other occasions to repair it. Because the economic resources to do this must be raised and managed locally, it is now more reluctant to do it (Table 7).

The situation in SP is very different. The ejido has a plan for forest management that has fostered timber exploitation and payment for environmental services. This includes among its norms the prohibition of garbage and care for water. In addition, in the ejido there is an organizational tradition around water 
Cuadro 7. Modelos de gestión del agua

Table 7. Water management models.

\begin{tabular}{|c|c|c|}
\hline & Colonia Veracruz & San Pedrito \\
\hline Administración & $\begin{array}{l}\text { Gestión municipal para la obtención del } \\
\text { pozo } 21 \text {. } \\
\text { Gestión local para la administración de } \\
\text { pozo } 21 \text {. } \\
\text { Gestión local de pozo } 57 \text { por grupo de pro- } \\
\text { ductores. } \\
\text { Canal de Tezontepec es responsabilidad del } \\
\text { municipio. }\end{array}$ & $\begin{array}{l}\text { El comité de agua se coordina para activi- } \\
\text { dades de mantenimiento de manantiales, } \\
\text { depósitos y tubería con el gobierno muni- } \\
\text { cipal y las comunidades. } \\
\text { Las comunidades aguas abajo tienen la } \\
\text { obligación de realizar faenas de manteni- } \\
\text { miento en el bosque, los manantiales y las } \\
\text { tuberías (dos faenas/ usuario al ańo) ade- } \\
\text { más de aportar una cuota de } 500 \text { pesos } \\
\text { anuales. } \\
\text { A la cabecera municipal no se le cobra el } \\
\text { agua, pero a cambio el municipio propor- } \\
\text { ciona plata coloidal y materiales para man- } \\
\text { tenimiento de depósitos y tuberías. }\end{array}$ \\
\hline Métodos para control de la calidad & $\begin{array}{l}\text { Clorador automático para pozo } 21 \text { no fun- } \\
\text { ciona. } \\
\text { El pozo } 57 \text { no se clora porque el agua es } \\
\text { para riego. } \\
\text { El canal proveniente de Tezontepec recibe } \\
\text { dos cloraciones aguas arriba, aunque en el } \\
\text { análisis de laboratorio no se detectó cloro y } \\
\text { sí coliformes. }\end{array}$ & $\begin{array}{l}\text { Antes la cloración se realizaba en depósitos } \\
\text { de distribución. Actualmente se usa plata } \\
\text { coloidal. }\end{array}$ \\
\hline Problemática & $\begin{array}{l}\text { Pozo } 21 \text { no funciona. } \\
\text { Clorador sólo funcionó al momento de la } \\
\text { instalación; no se volvió a suministrar clo- } \\
\text { ro. } \\
\text { Morosidad en el pago del servicio por parte } \\
\text { de los usuarios. } \\
\text { Calidad deficiente del agua del canal de } \\
\text { Tezontepec, la cual no se puede usar para } \\
\text { consumo humano. Considerable gasto en } \\
\text { la compra de agua (garrafón). }\end{array}$ & $\begin{array}{l}\text { Escasez de agua en tiempo de estiaje para } \\
\text { las comunidades que no tienen tuberías di- } \\
\text { rectas del manantial. } \\
\text { Rompimiento de tuberías. }\end{array}$ \\
\hline
\end{tabular}

ejido existe tradición organizativa en torno al manejo del agua. El comité de agua coordina la conservación de manantiales, reforestación, mantenimiento del repartidor y tuberías de distribución, así como la vigilancia de las principales fuentes de agua (Cuadro 7).

El ejido de SP maneja el agua mediante convenio con el gobierno municipal y las comunidades a las que abastece. El convenio establece los siguientes intercambios inter-comunitarios: el gobierno municipal provee de obras de mantenimiento y plata coloidal para el tratamiento del agua. Las comunidades que reciben agua realizan dos faenas de mantenimiento por usuario al año y reforestación en zonas de manantiales, además de vigilar y reparar tuberías. Las comunidades que tienen tubería directa (con excepción de la cabecera municipal) deben contribuir además con 500 pesos anuales por comunidad. Es management. The water committee coordinates the conservation of springs, reforestation, maintenance of the delivery system and distribution pipes, as well as the vigilance of the main sources of water (Table 7).

The SP ejido manages water through an agreement with the municipal government and the communities it supplies. The agreement establishes the following inter-community exchanges: the municipal government provides maintenance works and colloidal silver for water treatment. The communities that receive water carry out two maintenance tasks per user per year, and reforestation in spring zones, in addition to supervising and repairing the piping. The communities that have direct piping (with exception of the municipal township) must contribute an additional 500 pesos annually per community. That is, there is organization that involves the localities 


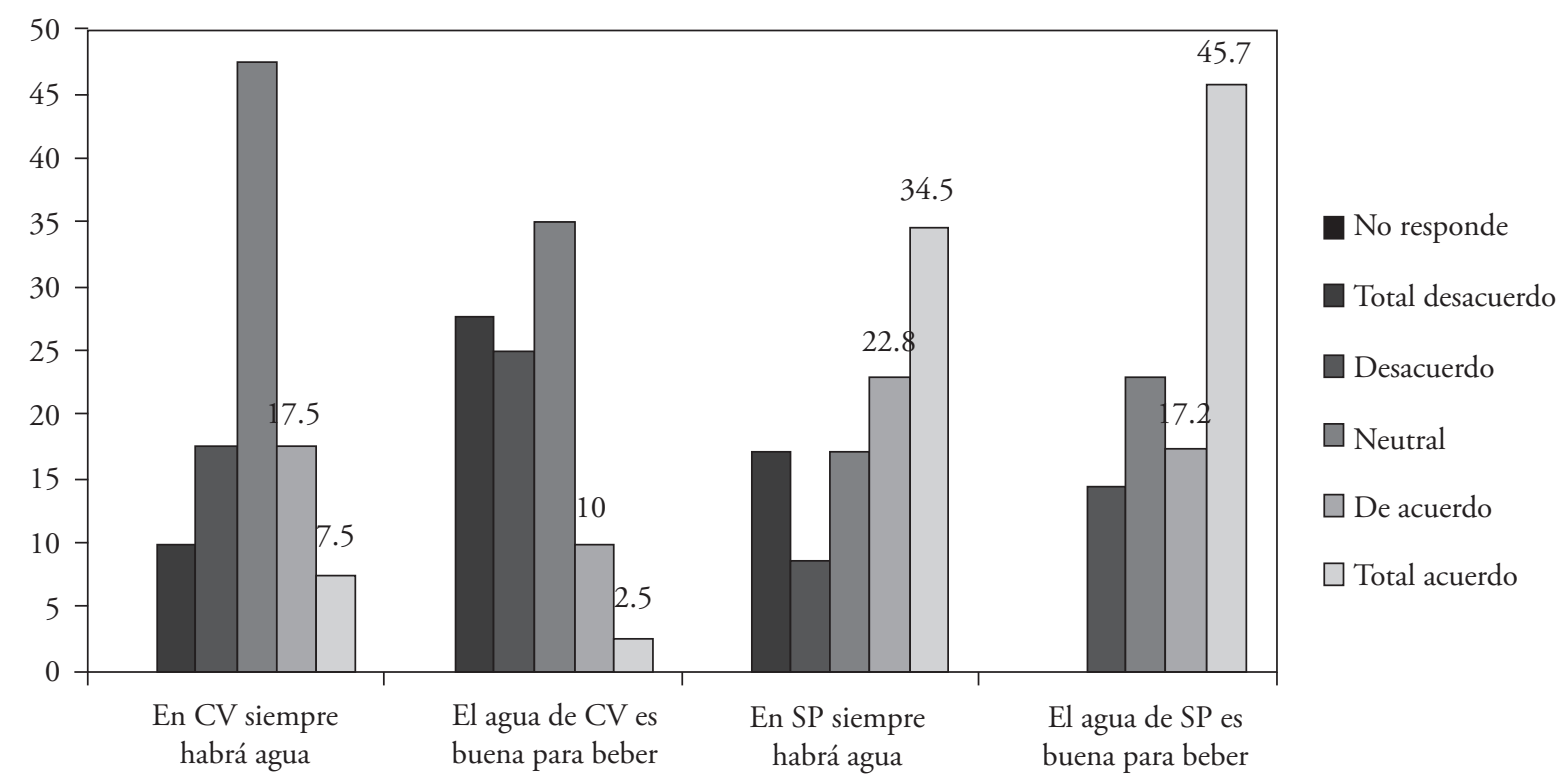

Figura 2. Opinión de las mujeres sobre cantidad y calidad del agua (\%) Figure 2. Women's opinion of the quantity and quality of water (\%).

decir, existe organización que involucra a localidades ubicadas más allá del ejido, bajo el principio de que el agua es retribuida con inversión de parte del gobierno municipal (obras, plata coloidal), trabajo no pagado y cuotas comunitarias.

Las diferencias en las formas de gestión se expresan en la visión de las mujeres. Las de SP tienen una mirada más optimista sobre la disponibilidad y calidad del agua a futuro, a pesar de que ésta se comparte con muchas comunidades, a diferencia de $\mathrm{CV}$, donde el comité maneja la principal fuente de agua para uso doméstico, el pozo 21 (Figura 2). Es decir, la situación administrativa es más compleja en SP desde el punto de vista del número de usuario/as y, a pesar de ello, el ejido está más organizado y da mejores resultados. Esto demuestra que la eficiencia en la gestión tiene más que ver con la solidez de estructuras organizativas que con la complejidad del sistema.

\section{Conclusiones}

El presente artículo se propuso analizar el ejercicio del derecho humano al agua de las mujeres de Hidalgo, utilizando cuatro variables: servicios de la vivienda, disponibilidad, calidad y eficiencia en la gestión del agua. La investigación fue realizada con fines comparativos en dos ejidos: $\mathrm{CV}$, del Valle del Mezquital (VM) y SP, de la Zona Otomí Tepehua beyond the ejido, under the principle that water is remunerated with investment from the municipal government (works, colloidal silver), unpaid work and community fees.

The differences in the forms of management are expressed in the women's viewpoints. Those from SP have a more optimistic view on availability and quality of water in the future, although it is shared with many communities; in contrast with $\mathrm{CV}$, where the committee manages the main source of water for domestic use, Well 21 (Figure 2). That is, the administrative situation is more complex in SP from the point of view of the number of users and, in spite of this, the ejido is more organized and has better results. This proves that the efficiency in management has more to do with the soundness of the organizational structures than with the complexity of the system.

\section{Conclusions}

This study attempted to analyze the exercise of the human right to water of women in Hidalgo, using four variables: household services, availability, quality and efficiency in water management. The research was performed with comparative goals in two ejidos: CV, from Valle del Mezquital (VM) and SP, from the Otomí Tepehua Zone (ZOT). The first 
(ZOT). La primera región hace considerables aportes al PIB estatal, mientras que la segunda ha sido catalogada como la más pobre del estado. Esta última sección resume y reflexiona sobre los principales hallazgos.

La primera variable se refiere a los servicios de agua para uso doméstico. En $\mathrm{CV}$ todas las viviendas reciben agua por tubería, a diferencia de SP donde una cuarta parte no está conectada a la red. En relación con la disponibilidad, todas las mujeres de CV dijeron sufrir de escasez debido a que el pozo de agua potable dejó de funcionar por morosidad en los pagos y adeudos de electricidad. En SP los indicadores son más favorables: $60 \%$ padece escasez, particularmente en el mes de mayo. La variable de calidad del agua para consumo humano también favorece a SP. El pozo de agua potable de CV tiene un clorador automático que no funciona, mientras que en SP se utiliza plata coloidal en los depósitos de agua. En CV, sólo $48 \%$ de las mujeres dijeron que el agua que reciben en casa es de calidad, contra $100 \%$ de las de SP. Los datos de laboratorio indican que el tratamiento de agua con plata coloidal de SP ha sido exitoso, a diferencia de $\mathrm{CV}$, donde la calidad de agua es dudosa y la población compra garrafones para consumo humano.

En términos de eficiencia en la gestión, SP también tiene mejores desempeños. El comité de aguas de $\mathrm{CV}$ no ha podido resolver la morosidad de pagos y el endeudamiento con la compañía de luz, por lo que el pozo de agua potable no funciona. Se tiene autonomía de gestión del gobierno municipal, pero dicha autonomía es inoperante. Por el contrario, el ejido forestal de SP abastece a once comunidades en total. La relación con el gobierno municipal es positiva en el sentido de que éste abastece de obras e insumos para mantener la calidad del agua, mientras que las comunidades aguas abajo aportan trabajo no pagado y una cuota para conservar las fuentes de abastecimiento. A pesar de que la gestión del agua en SP es más compleja que en $\mathrm{CV}$ porque implica una gran cantidad de actores, $57.3 \%$ de las mujeres de este ejido forestal piensan que siempre habrá agua para uso doméstico y $62.9 \%$ confía en su calidad, mientras que sólo 25 $\%$ y $12.5 \%$ de las mujeres de CV, respectivamente, se expresaron de esta manera sobre la disponibilidad y calidad del agua de uso doméstico en su ejido.

Los resultados invitan a la reflexión sobre la compleja relación entre desarrollo, género y derechos humanos; en específico, el referente al agua. $\mathrm{CV}$ es un region made considerable contributions to the state GDP, while the second has been catalogued as the poorest in the state. This last section summarizes and reflects upon the main findings.

The first variable refers to water services for domestic use. In CV, all the households received piped water, in contrast with SP where a fourth part is not connected to the network. With regard to the availability, all women in $\mathrm{CV}$ mentioned suffering from scarcity because the water well ceased to function as the result of delay in payment and an electric power debt. In SP the indicators are more favorable: $60 \%$ suffers scarcity, particularly in the month of May. The variable of water quality for human consumption also favors SP. The drinking water well in CV has an automatic chlorinator that does not work, while colloidal silver is used in SP for its water deposits. In $\mathrm{CV}$, only $48 \%$ of women said that the water they receive at home is of quality as opposed to $100 \%$ of women in SP. Data from the laboratory indicate that water treatment with colloidal silver in SP has been successful, in contrast to $\mathrm{CV}$, where the water quality is uncertain and the population purchases bottles for human consumption.

In terms of management efficiency, SP also has a better performance. The water committee in CV has not been able to solve the delay in payment and the debt with the electricity company, which is why the drinking water well does not function. There is management autonomy from the municipal government, although this autonomy is inoperative. On the contrary, the forest ejido of SP supplies eleven communities in total. The relationship with the municipal government is positive in the sense that it supplies works and inputs to maintain the water quality, while the communities downstream contribute unpaid work and a fee to conserve the sources of supply. Although water management in $\mathrm{SP}$ is more complex than in $\mathrm{CV}$, because it involves a large number of actors, $57.3 \%$ of the women in this forest ejido think that there will always be water for domestic use and $62.9 \%$ trusts in its quality, while only $25 \%$ and $12.5 \%$ of women in CV, respectively, expressed the same about availability and quality of water for domestic use in their ejido.

These results stimulate a reflection about the complex relationship between development, gender and human rights; specifically, the one referring to water. $\mathrm{CV}$ is an ejido with better indicators of 
ejido con mejores indicadores de crecimiento económico y servicios de agua en la vivienda, pero tiene severos problemas de disponibilidad y calidad. Por el contrario, SP se encuentra en una región identificada como pobre desde el punto de vista económico que, sin embargo, cuenta con mayor eficiencia organizativa para la gestión del agua, la cual incluso trasciende las fronteras del ejido. Esto se ha traducido en menor escasez y mayor calidad del agua.

Los problemas de escasez, falta de calidad y deficiente gestión ponen en riesgo el ejercicio del derecho humano al agua de las mujeres. Algunas de sus implicaciones son: sobrecargas de trabajo para abastecerse de otras fuentes y cuidar enfermos/as; gastos adicionales para comprar agua; y reducción de actividades de traspatio, como la crianza de animales. Como responsables de todas las tareas domésticas, las mujeres son las primeras afectadas por esta situación. Es necesario explorar detalladamente estas circunstancias en futuras investigaciones. Hacerlo permitirá dilucidar con mayor profundidad los obstáculos que enfrentan las mujeres del campo para ejercer plena y efectivamente el derecho humano al agua.

El presente estudio confirma que el crecimiento económico produce y recrea nuevas desigualdades entre hombres y mujeres, ricos y pobres, así como entre distintas regiones al interior de un país o de un mismo estado. Más allá de la democracia formal, la ampliación de la cartera de derechos humanos mantiene viva la esperanza de reducir estas desigualdades. Una pre-condición para que esto suceda es difundir muy ampliamente los contenidos del derecho humano al agua entre las poblaciones más afectadas por los problemas de servicios, disponibilidad, calidad e ineficiencia de gestión descritos en este trabajo.

No hay indicador de rendimiento económico que pueda compensar la vulnerabilidad hídrica que viven las mujeres de Hidalgo y, en particular, las de CV, ante la falta de agua segura, asequible y de calidad. Es muy probable que esta situación se repita en otras partes del país. De acuerdo con la constitución, corresponde al Estado garantizar el derecho humano al agua de los y las mexicanas. Queda pendiente realizar más trabajo de investigación, vinculación y divulgación para que los derechos ganados en papel se traduzcan en ganancias reales para las mujeres rurales de Hidalgo y del resto de México. economic growth and water services in households, although it has grave problems of availability and quality. On the contrary, SP is located in a region identified as poor from the economic point of view, which, however, has greater organizational efficiency for water management, which even transcends the ejido borders. This has translated into lower scarcity and greater quality of water.

The problems of scarcity, lack of quality and deficient management place at risk women's exercise of the human right to water. Some of their implications are: work overloads from obtaining supply from other sources and caring for sick persons; additional expenses to purchase water; and reduction of backyard activities, such as animal breeding. As those responsible for all the domestic tasks, women are the first to be affected by this situation. It is necessary to explore these circumstances in detail in future research. Doing this will allow elucidating with greater depth the obstacles that women in the countryside face to exercise fully and effectively the human right to water.

This study confirms that economic growth produces and recreates new inequalities between men and women, rich and poor, as well as between different regions inside a country or a state. Beyond formal democracy, the expansion of the portfolio of human rights keeps alive the hope of reducing these inequalities. A pre-condition for this to happen is to divulge very broadly the contents of the human right to water among the populations most affected by problems of service, availability, quality and inefficiency in management described in this work.

There is no indicator of economic performance that could compensate for the water vulnerability that women experience in Hidalgo and, particularly, in $\mathrm{CV}$, when facing the lack of safe, affordable and quality water. It is very likely that this situation is repeated in other parts of the country. According to the constitution, it is the responsibility of the State to guarantee the human right to water of Mexican citizens. It is still pending to perform more research work, as well as correlation and dissemination, for the rights attained on paper to be translated into actual benefits for rural women in Hidalgo and the rest of México.

\section{- End of the English version -}




\section{Notas}

${ }^{3}$ Agradecemos el apoyo financiero del Instituto Hidalguense de las Mujeres para realizar la investigación. Este taller fue convocado por su personal y realizado en sus instalaciones. We are grateful for the financial support from Instituto Hidalguense of Women to perform the research. This workshop was called for by its staff and took place in their facilities.

\section{Literatura Citada}

Aboites Aguilar, Luis. 1998. El agua de la nación: una historia política de México 1988-1946, México, CIESAS.

Agarwal, Anil, and Sunita Narain. 1991. Dying wisdom: rise, fall and potential of Indian's traditional water harvesting systems, India, CSE.

Amemiya Ramírez, Michiko. 2006. El derecho al agua. In: Denise Soares Moraes, Verónica Vázquez García, Ángel Serrano Sánchez y Aurelia de la Rosa Regalado (coords), Gestión y cultura del agua. Tomo 1. México, Instituto Mexicano de Tecnología del Agua y Colegio de Postgraduados. pp: 23-43.

Ángeles Ángeles, Luis. 2011. Estudiar la pobreza en el estado de Hidalgo. In: Pobreza y migración. Aportes para el desarrollo del estado de Hidalgo, México. Miguel Ángel Porrúa y El Colegio del Estado de Hidalgo. pp: 11-39.

Bautista Olivas, Ana Laura, Jorge Leonardo Tovar Salinas, Oscar Raúl Mancilla Villa, Héctor Magdaleno Flores, Carlos Ramírez Ayala, Ramón Arteaga Ramírez, y Mario Vázquez Peña. 2013. Calidad microbiológica del agua obtenida por condensación de la atmósfera en Tlaxcala, Hidalgo y Ciudad de México. Revista Internacional de Contaminación Ambiental vol. 29, núm. 2. pp: 167-175.

Bello, Álvaro. 2008. Prólogo. In: Álvaro Bello y José Aylwin (coords), Globalización, derechos humanos y pueblos indígenas, Temuco, Chile, Grupo Internacional de Trabajo sobre Asuntos Indígenas. pp: 11-18.

Benería, Lourdes, and Gita Sen. 1997. Accumulation, reproduction and women's role in economic development: Boserup revisited. In: Nalini Visvanathan, Lynn Dugan, Laurie Nisonoff y Nan Wiegersma (eds), The women' gender and development reader. London, Zed Books. pp: 42-50.

Bonfil, Paloma, y Raúl Marco Del Pont. 1999. Las mujeres indígenas al final del milenio, México, Comisión Nacional de la Mujer.

Boserup, Ester. 1970. Women's role in economic development, London, George Allen \& Unwin.

Carmona, Edith, Pilar Alberti, y Emma Zapata. 1998. Acceso y uso del agua por las campesinas en la unidad doméstica y la parcela agrícola de riego. Alto Río Lerma, Guanajuato, Comunicaciones en Socioeconomía, Estadística e Informática vol. 2, núm. 6. pp: 5-25.

Castro, José Esteban. 2007. El estudio interdisciplinario de los conflictos por el agua en el medio urbano: una contribución desde la sociología, Cuadernos del Cendes vol. 24, núm. 66. pp: 21-46.

Centro Mexicano de Derecho Ambiental, Red Guerrerense de Organismos de Derechos Humanos, Todos los Derechos para Todos y Todas, Flor y Canto A.C., Asociación Jaliciense de Apoyo a Grupos Indígenas A.C., Centro Fray Julián Garcés, Coordinadora por un Atoyac con Vida, Instituto Mexicano para el Desarrollo Comunitario y Coalición de Organizaciones Mexicanas por el Derecho al Agua. 2011. Informe sobre el derecho humano al agua en México presentado en el 143 periodo de sesiones de la Comisión Interamericana de Derechos Humanos. 19 de octubre al 4 de noviembre de 2011, disponible en http://www.redtdt.org.mx/media/descargables/Informe $\% 20$ sobre $\% 20 \mathrm{el} \% 20$ Derecho $\% 20$ Humano\%20al\%20Agua\%20en\%20M_xico-1.pdf (consultado el $17 / 01 / 2014)$.

CEEH (Consejo de Ecología del Estado de Hidalgo). 2011. Nuestro territorio. disponible en http://coedeh.hidalgo.gob. $\mathrm{mx} /$ index.php?option=com_content $\&$ task=view \&id=30\&It emid=53 (consultado el 27/01/2011).

CONAPO (Consejo Nacional de Población). 2010. Índices de marginación por entidad federativa. disponible en http://www.conapo.gob.mx/index.php?option=com_con tent\&view=article\&id=478\&Itemid=194 (consultado el 10/12/2011).

Cruz Sánchez, Armando. 2011. Se riegan con aguas negras $60 \%$ de cultivos agrícolas en Hidalgo. La Jornada, México. 12 de marzo de 2011. pp: 32.

Domínguez, Judith, Diana Martínez, Anabel Palacios, y Alejandra Peña. 2013. El monitoreo social del derecho humano al agua y saneamiento, México, Colegio de México.

Esteva, Gustavo. 1996. Desarrollo. In: W. Sachs (ed), Diccionario del desarrollo. Una guía del conocimiento como poder. Perú, PRATEC. pp: 52-79.

Galindo Escamilla, Emmanuel, y Jacinta Palerm Viqueira. 2012. Toma de decisiones y situación financiera en pequeños sistemas de agua potable: dos casos de estudio en El Cardonal, Hidalgo, Región y Sociedad, vol. 24, núm. 54, mayo-agosto. pp: 261-298.

García, Aniza. 2008. El derecho humano al agua, Madrid, Editorial Trotta.

García Dávila, Alejandrina. 2012. Género, etnia y manejo del agua en la Sierra Mazateca, Tesis de Maestría en Ciencias, Desarrollo Rural, Colegio de Postgraduados.

Hernández Castillo, Rosalva Aída, y Liliana Suárez-Navaz. 2004. Las fronteras y las panaceas del desarrollo en México y España. Reflexiones desde los feminismos poscoloniales, Liminar. Estudios Sociales y Humanísticos, vol. 2, núm. 1, enerojunio. pp: 7-24.

IIDH (Instituto Interamericano de Derechos Humanos). 2008. Guía de capacitación de derechos humanos de las mujeres, San José, Costa Rica, IIDH.

INEGI (Instituto Nacional de Estadística, Geografía e Informática). 2010. Panorama sociodemográfico de México, Aguascalientes, INEGI.

Jiménez Cisneros, Blanca, y Alma Chávez Mejía. 2011. Efectos por el empleo del agua residual de la ciudad de México para riego en el Valle de Tula. In: Agua y medio ambiente. Aportes para el desarrollo del estado de Hidalgo, México, Miguel Ángel Porrúa y El Colegio del Estado de Hidalgo. pp: 91-124. 
Kabeer, Naila. 1995. Reversed realities. Gender hierarchies in development thought, London, Verso.

Langford, Malcolm, y Ashfaq Khalfan. 2006. Introducción al agua como derecho humano. In: Sofía Esch, Martha Delgado, Silke Helfrich, Hilda Salazar Ramírez, María Luisa Torregrosa e Iván Zúñiga Pérez-Tejada (coords), La gota de la vida. Hacia una gestión sustentable y democrática del agua, México, Fundación Heinrich Boll, México. pp: 30-62.

Moser, Caroline. 1993. Gender planning and development. Theory, practice and training, New York, Routledge.

Nazar, Austreberta, Emma Zapata, y Verónica Ramírez. 2010. Género y agua. Estrategias para alcanzar la sustentabilidad con equidad. In: Blanca Jiménez, María Luisa Torregosa, Luis Aboites (coords), El agua en México, cauces y encauses, México, Academia Mexicana de Ciencias, Comisión Nacional del Agua. pp: 383-410.

OEIDRUS (Oficina Estatal de Información para el Desarrollo Rural Sustentable). 2014. Distrito de Desarrollo Rural Tulancingo. Fichas Municipales, disponible en http://www. campohidalguense.gob.mx/ (consultado el 13/03/2014).

Ortega Marín, Blanca Andrea. 2011. Caracterización del recurso hídrico en el estado de Hidalgo. In: Agua y medio ambiente. Aportes para el desarrollo del estado de Hidalgo, México, Miguel Ángel Porrúa y El Colegio del Estado de Hidalgo. pp: 11-30.

Ostrom, Elinor. 2000. El gobierno de los bienes comunes: la evolución de las instituciones de acción colectiva, México, UNAM-FCE.

Rai, Shirin M. 2002. Gender and the political economy of development, Cambridge, Polity Press.

Ramírez Flores, Elizabeth, Esperanza Robles Valderrama, Reynaldo Ayala Patiño, y Blanca Martínez Rodríguez. 2012. Calidad amebológica del agua de pozos utilizados para suministro de agua potable en el Estado de Hidalgo, Ingeniería, Revista Académica de la FI-UADY, vol. 16, núm. 3. pp: 219 228.

REGEMA (Red de Género y Medio Ambiente). 2006. La agenda azul de las mujeres, México, REGEMA, PNUD, SEMARNAT e IMTA.

Rico, María Nieves. 2006. Género y agua. In: Sofía Esch, Martha Delgado, Silke Helfrich, Hilda Salazar Ramírez, María Luisa Torregrosa e Iván Zúñiga Pérez-Tejada (coords), La gota de la vida. Hacia una gestión sustentable y democrática del agua, México, Fundación Heinrich Boll. pp: 255-264.

Robles Berlanga, Rosario. 2000. Voces de las mujeres. La experiencia de las indígenas del Valle del Mezquital. In: Josefina Aranda, Carlota Botey y Rosario Robles (eds), Tiempo de crisis, tiempo de mujeres, Oaxaca, UABJO. pp: 157-232.
Salazar, Rebeca, Hilda Salazar, Brenda Rodríguez, y Maritza Rodríguez. 2012. Agenda de género y agua en Iztapalapa: acciones para el disfrute del derecho humano al agua, México, Mujer y Medio Ambiente A.C. y Gobierno de la Ciudad de México.

Santillán Arias, Amalia. 2011. Identificación de impactos ambientales en el distrito de riego 03-Tula por el uso de aguas residuales. In: Agua y medio ambiente. Aportes para el desarrollo del estado de Hidalgo, México, Miguel Ángel Porrúa y El Colegio del Estado de Hidalgo. pp: 59-90.

SEMARNAT (Secretaría de Medio Ambiente y Recursos Naturales). 2012. Informe de la situación del medio ambiente en México, México, SEMARNAT, disponible en http://app1. semarnat.gob.mx/dgeia/informe_12/pdf/Informe_2012.pdf (consultado el 17/01/2014).

Soares, Denise. 2006. Mujeres, agua, leña y desarrollo: estudio de caso sobre género y recursos naturales en los Altos de Chiapas. In: Denise Soares Moraes, Verónica Vázquez García, Ángel Serrano Sánchez y Aurelia de la Rosa Regalado (coords), Gestión y cultura del agua, Tomo II, México, Instituto Mexicano de Tecnología del Agua y Colegio de Postgraduados. pp: 292-312.

Solarte, Yezid, Miguel Peña, y Carlos Madera. 2006. Transmisión de protozoarios patógenos a través del agua para consumo humano, Colombia Médica vol. 37, núm. 1. pp: 74-82.

Vargas González, Pablo. 2011. Pobreza, migración y desempleo: mujeres en la región otomí-tepehua de Hidalgo, Nueva Antropología, vol. 24, núm. 75, julio-diciembre. pp: 93-109.

Vázquez García, Verónica, y Carolina Muñoz Rodriguez. 2011. Diagnóstico sobre medio ambiente y desarrollo sustentable con perspectiva de género en el estado de Hidalgo, Pachuca, Instituto Hidalguense de las Mujeres.

Villavicencio Nieto, Miguel Ángel; Blanca Estela Pérez Escandón, y Alberto José Gordillo Martínez. 2010. Plantas tradicionalmente usadas como plaguicidas en el estado de Hidalgo, México, Polibotánica núm. 30. pp: 193-238.

Villavicencio, Miguel Ángel, y Blanca Estela Pérez Escandón. 2005. Guía de la flora útil de la Huasteca y la Zona OtomíTepehua, Hidalgo, Pachuca, Universidad Autónoma del Estado de Hidalgo.

Wade, Robert. 1988. Village republics: economic conditions for collective action in South India, USA, Cambridge University Press.

Young, Kate. 1997. Gender and Development. In: Nalini Visvanathan, Lynn Dugan, Laurie Nisonoff, Nan Wiegersma (eds), The Gender and Development Reader. London, Zed Books. pp: 51-54. 